European Journal of Accounting, Auditing and Finance Research

Vol.8, No.2, pp.81-99, February 2020

Published by ECRTD-UK

Print ISSN: 2053-4086(Print), Online ISSN: 2053-4094(Online)

\title{
EVALUATION OF INTERNAL CONTROL SYSTEM ON THE PERFORMANCE OF COOPERATIVE SOCIETIES IN SELECTED TERTIARY INSTITUTIONS IN ONDO STATE, NIGERIA
}

\author{
Olowolaju, Philip Segun \\ Department Of Accounting, Federal University Of Technology, Akure, Nigeria \\ E-Mail: olowosegun2014@ gmail.com
}

\author{
Adeyemo, Foluke Helen \\ Department Of Project Management Technology, Federal University Of Technology, Akure, \\ Nigeria \\ E-Mail: fhadeyemo@gmail.com
}

\begin{abstract}
The study assessed the internal control systems on performance of cooperative societies in some selected tertiary institutions in Ondo States, Nigeria. A stratified sampling technique was adopted for the study. The data were collected from members of registered cooperative societies in the selected tertiary institutions in the study area using structured questionnaire. The statistical tools used include de, Likert ratings, regression analysis and paired sample t-test. Results revealed that the selected cooperative societies often use all the key internal control measures which influence their performance, which include authorization measure $(p=0.027)$, arithmetic and accounting measures $(p=0.000)$, as well as budgetary measures ( $p=0.001$. The study recommended that cooperative societies in the tertiary institutions should strengthen their internal controls to ensure good performance
\end{abstract}

KEY WORDS: cooperative, performance, internal control, tertiary, institutions, loans,

\section{INTRODUCTION}

Cooperative financing has been a major source of finance to many people in Nigeria especially salaried workers. Almost every tertiary institution in Nigeria has cooperative societies to cater for the financing need of their members. Different categories of staff were employed by these tertiary institutions which include academic staff, non-academic staff, technical staffs and senior staff. These staff usually arranged themselves into different cooperative societies in order to save money for future capital budget such as paying their children school fees, buying cars, building houses, purchase of landed properties and so on. These cooperative societies therefore must be well managed and well-structured in order to prevent embezzlement and mismanagement of contributed funds so that the cooperative society can meet the aspirations of their founding members and those who will later join the society. Adequate Internal control system (ICS) is very fundamental component of the risk management systems in cooperative societies.

For any cooperative society to meet the needs and yearnings of its members and safeguard tts assets, it must be able to manage its business process which is a reason why ICS is very crucial (Robbins, 1992). There are several cases of fraudulent practices among credit and thrift 
European Journal of Accounting, Auditing and Finance Research

Vol.8, No.2, pp.81-99, February 2020

Published by ECRTD-UK

Print ISSN: 2053-4086(Print), Online ISSN: 2053-4094(Online)

societies where some members will disappear into thin air after collecting soft loans from the society and usually the culprit are the key members of the society or group.

It has been observed that internal control system is one of the mechanisms that can be used to address cooperative society's problems, (Asiligwa and Rennox, 2017). Internal control system in any cooperative society should evolve over time and should have positive effect on the cooperative society performance. However, not all cooperative societies in Nigeria tertiary institutions have efficient internal control measures in place and as such some are still struggling with liquidity problems, untimely financial reports, inefficient accountability for the cooperative's financial resources, frauds and misuse of the cooperative's resources as well as a number of decisions made not yielding the expected results (Ejoh and Ejom, 2014). Few works have been done on internal control system in cooperative societies but not in tertiary institution. This study is specifically to evaluate the internal control system in the cooperative societies in some selected tertiary institutions in Ondo States, Nigeria, with a view to assessing the effect on the level of performance of these societies and satisfaction derived by the members from the societies.

\section{LITERATURE REVIEW}

The literature review consists of conceptual, empirical and theoretical reviews of previous works that are relevant to this study.

\section{Conceptual Review}

Generally, a cooperative society may be defined as an association of persons who pool their resources together on mutual basis to solve specific socio-economic problems, which may include income generating activities. A co-operative may also be defined as a self help organization. These associations may be formed by either producers or consumers. The initiative to form such cooperative usually arises from one or two people. These initiators then play an advocacy role and enlist other people to the co-operative. Often, the initiators become the key drivers of these projects and reap the consequent benefits as managers of these ventures. There are several types of co-operative societies in Nigeria. These include: Multipurpose, Marketing, Consumers, Processing, Industrial, Supply/purchasing, Credits and thrift co-operative societies (Otto and Ukpere, 2011). Co-operative societies in Nigeria operate at three levels: the primary, secondary and tertiary. The primary societies operate at the level of a community, the secondary society operate at the level of the local government area, while the tertiary or apex co-operative societies operates across the local government areas but within the state (Taylor, 1974).

The basic concept of internal control system as stated by Committee of Sponsoring Organizations on internal control frame work (COSO) is to identify risk, detect and prevent fraud in an entity. This concept is carried out with the use of some control activities. Control activities are the policies, procedure, techniques, and mechanisms that help ensure that management's response to reduce risks identified during the risk assessment process is carried out. 
European Journal of Accounting, Auditing and Finance Research

Vol.8, No.2, pp.81-99, February 2020

Published by ECRTD-UK

Print ISSN: 2053-4086(Print), Online ISSN: 2053-4094(Online)

\section{Internal Control Activities}

Control activities occur throughout the organizations at all levels and in all functions. Control activities are the policies and procedures used in various organizations to ensure that management directives are carried out and necessary actions are taken to address risks to ensure the achievement of various objectives (Ratcliffe and Landes, 2009). Mendoza (2012) list out in his research that the control activities of internal control systems in cooperatives governance can be divided into nine activities: Authorization, segregation of duties, information processing, physical controls, adequate documents, verification, reconciliation, review of operating performance and supervision. The objectives of the entity can be achieved through better control activities which mean that all necessary action should be taken with the aim to address risks.

Whittington and Pany(2001), mentioned that control activities are policies and procedures that help to ensure that management directives are carried out. Control activities in an entity basically comprise of performance reviews, information processing, documentation, authorization, verification, physical controls of assets and segregation of duties. According to Idowu and Adedokun (2013), control activities are the most viable element of internal control and arguably the most important in preventing wrong action from occurring. The need for a control activities is established in the risk assessment of an agency objective, a corresponding control activity or activities are determined and implemented (Ayodeji, 2017).

The control environment is the foundation for all other components of internal control that provide discipline and structure, which influence the control consciousness in an organisation (Ratcliffe and Landes, 2009). Ayagre, et al. (2014) found that control environment is considered effective if top management support for integrity and ethical values, establish codified standards of conduct to guide behavior, activities and decisions in order to pursue company objectives. For cooperative organizations, the factors related to the control include the integrity and ethical values, and commitment of the cooperative management ( Mary et al., 2014) Risk assessment is the process of identification and analysis of the internal and external risks which may affect the management, financial reporting and legal compliance (Takahiro \& Jia, 2012). In cooperatives organization, risk assessment is used by identifying and analyzing of relevant risks towards the achievement of the objectives and to determine how the risks should be solved (Mendoza, 2012) Mendoza stated further that control activities in an organisaton can be Authorization, segregation of duties, information processing, physical controls, adequate documents, verification, reconciliation, review of operating performance and supervision. Information and Communication is also an integral part of internal control system. It is imperative for entity to obtain and exchange the information in order to conduct, manage and controls its operation while the control activities are implemented (Frazer, 2011). Information system is also imperative to guide in organization operation process (Wardiwiyono, 2012). Monitoring is the last part of internal control components, which is referred to as "a process that assesses the quality of the system's performance over time. Monitoring plays an important role in the internal control system, it helps control internal maintains its effectiveness over different periods (Ayagre, 2014). 
European Journal of Accounting, Auditing and Finance Research

Vol.8, No.2, pp.81-99, February 2020

Published by ECRTD-UK

Print ISSN: 2053-4086(Print), Online ISSN: 2053-4094(Online)

\section{THEORETICAL REVIEW}

The most widely known and recognized theory, which backed the activities of the cooperative, is the "theory of Democracy. The principal objective of this theory is to make cooperative an easy and profitable organization in which their aims and objectives are achieved. The theory provides at least some of the materials required to make a realistic assessment of decision making in retail co-operatives Kareem, et al. (2012). Although, there is no agreed definition of democracy, even though a cursory study of the uses of the term by modern writers and politicians shows that there is no agreed meaning. Some equate it with the rule of the majority, others emphasis the importance of protecting the rights of the minority. Some regard it as a system which maintains certain valued institution, such as freedom of speech and association, while others said it is a way of totalitarian democracy. Co-operative democracy could be viewed as the democratically control in the co-operative set-up, that is, democracy within co-operatives (Arigbadu, 2012). The concrete elements in a co-operative democracy may of course, be different from those in a state democracy. For example, in a co- operative, the members take the place of the citizens and the Board of Directors take the place of the Government of the state. But these substitutions do not involve a change in the meaning of democracy and any conclusions, which hold good democracy within the states, will apply equally well to democracy within co-operative societies (Badmus,2012). The classical theory is more useful for analyzing the practice of retail co-operative government. In the early days of the movement, co-operatives approximated very closely to ideal direct democracy in which all the members meet together in terms of equality to make decisions. The representative executive body-"the Government" of the co-operative exercised only limited powers between general meetings and there was no sharp distinction between the execution and other members. In some societies, the execution would be chosen by a system of rotation rather than election and it was common practice for ordinary members to attend executive meetings. Today, even in the smallest societies, the roles of the executive and the members are clearly differential but the element of direct democracy remains relatively pronounced. Over the years, the indirect representative element in co-operative government has markedly increased, but all representative bodies remain, in theory at least, directly accountable to the business meeting as well as accountable to the membership through the election procedures. Other features of co-operative government underline its classical democratic character. Most obvious, perhaps, is the emphasis placed upon local democracy. Although the structure of the movement as autonomous local societies, seems to many observers as ill-adapted to modern trading conditions. . In theory, of course, it is possible to envisage as some reformist cooperators do, a single natural co-operative society constructed according to the canons of representatives classical democracy.

The study is based on performance of cooperative societies, thus resource based theory is relevant to the study. Resource-based theory, like all theories, is based on several assumptions. Some of these assumptions are mainly linked to persistent superior firm performance theories. In particular, they focus on how to measure superior performance in order to evaluate a firm's competitiveness. Resource-based logic, for instance, adopts the assumption that firms are 
European Journal of Accounting, Auditing and Finance Research

Vol.8, No.2, pp.81-99, February 2020

Published by ECRTD-UK

Print ISSN: 2053-4086(Print), Online ISSN: 2053-4094(Online)

profit-maximizing entities and that managers in firms are bounded to be rational (Simon, 1945).

Over and above these basic assumptions, resource-based logic makes two additional issues that distinguish it from other strategic management theories: the concept of resource heterogeneity and that of resource immobility (Barney, 1991). These assumptions are that resource heterogeneity: competing firms may possess different bundles of resources and for Resource immobility, these resource differences may persist. One critical aspect is that these two assumptions may exist. This means that some firms may have or control resources that can enable them to effectively conceive and implement more successful strategies than other firms over time. Besides, these resources can be either possessed or controlled by the firm: this implies they do not necessarily have to be owned within the firm's physical boundaries. The heterogeneity issue also incorporates two attributes of firm resources: scarcity and nonsubstitutability (Barney, 1991). A firm resource is considered to be scarce when the demand for that resource is greater than its supply. A resource is non- substitutable when no other resources can enable a firm to conceive of and implement the same strategies as efficiently or effectively as the original resource. The concept of immobility mainly refers to the issue of inelasticity in supply, that is, more of a particular resource is not forthcoming even though demand for that resource is greater than its supply. Firm resources may vary significantly in the extent to which they are scarce, non- substitutable, and inelastic in supply.

\section{Empirical Review of Literature}

Magara (2013) studied the effect of internal controls on the Cooperative Performance of deposit taking Savings and Credit Cooperative Societies (SACCOs) in Kenya. The study used the control environment, risk assessment, control activities and monitoring to proxy internal contro land they found that they contributed positively to the financial performance of SACCOs in Kenya. Ayagre, et al. (2014) carried out a study on the effectiveness of Internal Control Systems in Ghana cooperative societies:. The study evaluated the control environment and monitoring activities components of Internal Control Systems of Ghanaian Cooperative using COSO's principles and attributes of assessing the effectiveness of internal control systems. The study found out that, strong controls exist in the control environment and monitoring activities components of the internal control systems of cooperatives in Ghana. The study recommended that boards of cooperatives in Ghana should not be complacent about the findings but should work hard to ensure continuous ongoing and separate internal control monitoring to ascertain that controls really exist and are functioning properly.

Asiligwa and Rennox (2017) carried out a study guided by the Agency Theory to test empirically the effects of internal control on cooperative performance in tertiary institutions in Kenya. The study used a case study research design. The findings showed that inadequate staffing of the institutions internal audit effect the internal control of the cooperative societies performance. Hayali et al. (2014) studied the importance of internal control system in the cooperative societies: Evidence from Turkey. In this study, the importance of internal control system was expressed, also its impacts to the cooperative system analyzed. The research showed that the internal control activities of the cooperatives are adapted to the international 
European Journal of Accounting, Auditing and Finance Research

Vol.8, No.2, pp.81-99, February 2020

Published by ECRTD-UK

Print ISSN: 2053-4086(Print), Online ISSN: 2053-4094(Online)

standards in Turkey and effective control procedures existed in the cooperative system. In addition, efficient internal control mechanisms have great impact on the strong and stable outlook of Turkish cooperative societies.

Bayyoud and Sayyad (2015) studied the impact of internal control and risk management on cooperative in Palestine. The investigation helped in identifying the impacts of new cooperative reformations and rules on the risk assessment, identification, and mitigation in cooperative. The findings showed that overall internal control and risk management systems in Palestine have positively affected the cooperatives in terms of quantitative as well as qualitative performance.

\section{Survey of Thrift Societies in Selected Country}

The first credit society was formed by Herman Schulze-Delitsch in 1851 to provide credit facilities for debt-ridden peasant farmers in Germany (Taylor, 1974). Co-operative credit associations have been found in several countries to be well suited to providing loan facilities and stimulating savings as evidenced from the study of selected countries further discussed.

In Ghana, credit and thrift societies are owned, managed and controlled by the people of the areas in which they are located (Agwu, 2006). They are responsible for financing cooperative as well as members within each catchment area. Thus, the main task of these credit cooperatives were to mobilize savings from the area and to on-lend such savings to deserving customers of the area, to enable them improve their productivity. These credit cooperatives ensure that credits are made to agriculture and other priority rural activities and also to the small rural borrower. To enhance borrowers' effective utilization of loans, a proper monitoring is carried out and assistance in terms of procuring needed inputs is also offered (Agwu, 2006).

The most widespread application of co-operative thrift society has been in India, where the problem of peasant indebtedness and greedy moneylenders has been particularly serious issue (Otto and Ukpere, 2011). In India, co-operative banks and loan societies actually made an inroad into the rural areas, mainly as a result of official initiative and encouragement. The structures of co-operative banks were biased in favour of their occupations, which are agricultural co-operatives, employee's co-operatives, business co-operatives and industrial co-operatives. The co-operative credit structure for short and medium term credit is a three tier one, with a State cooperative bank at the apex in each state, the central cooperatives at the district level and the primary credit societies at the base. This has greatly improved the financing of agriculture and small scale enterprises and led to rising trend in output. 
Cooperatives society in Nigeria are community-based, rooted in democracy, flexible and have participatory involvement, which makes them well suited for economic development (Gertler, 2001). The process of developing and sustaining a cooperative involves the processes of developing and promoting community spirit, identity and social organisation as cooperatives play an increasingly important role worldwide in poverty reduction, facilitating job creation, economic growth and social development (Gibson, 2005). There is hardly any workplace in Nigeria today, particularly government establishments, where at least a cooperative society is not operational (Kareem, Arigbadu, Akintaro and Badmus, 2012). Their operations are quite effective because transactions of money are carried out in conjunction with the employers on behalf of the staff. For example, staff savings into cooperatives are deducted at source and repayment of loans is also done through deduction from staff salaries as instructed by the operators of the societies (Kareem, et al., 2012).

\section{Conceptual Framework}

The Resource-based Theory was adopted as the conceptual framework for this study.

Resource-based theory focuses on how to measure superior performance in order to evaluate a firm's competitiveness. As shown in Figure 2.2, the conceptual framework reveals that the performance of cooperative societies (PCS) is being affected majorly by internal control system (ICS) as well as the factors affecting the internal control system (FA). This simply implied that since internal control system affect the performance of cooperative societies, the factors that affect the internal control system is bound to also directly or indirectly affect the performance of cooperative societies. The performance of cooperative societies as shown in the figure is often determined by capital share and dividends, 
Adequate and timely loan disbursement, investments, as well as the membership of the cooperative society. The key types of internal control system include the physical control, authorization control, personnel control, arithmetic and accounting, management control and organizational control. Others include supervision control, segregation of duties, acknowledgement of performance and budget/ budgetary control. However, the key factors that affect the internal control system and consequently affect the performance of the cooperative societies include mode of loan repayment, nature of collateral policy, level of segregation of duties and the process involved in the granting of loans.

\section{METHODOLOGY}

Surveyed design was used and the methods of data collections employed for the research was questionnaire. Seven (7) cooperative societies from four (4) selected tertiary institutions in Ondo State Nigeria were used for this study, two (2) cooperative societies each from three government owned institutions and one from a privately owned institution. The total number of members of the seven selected cooperative societies were 4936 The sample size from each cooperative society was determined using Taro Yamane (1967). The total sample size was 371. Data were analysed using percentages, likert rating regression analysis and paired sample t-test.

\subsection{Model Specification for Regression Analysis}

The model specification for regression analysis is as follows:

$\checkmark$ Dependent Variable; $\mathrm{Y}$ is the Performance of Cooperative Societies (PCS),

$\checkmark$ Independent Variables; $x_{1}, \mathrm{x}_{2} \ldots \ldots \ldots \mathrm{x}_{\mathrm{n}-1}, \mathrm{x}_{\mathrm{n}}$ are the Internal Control Systems

$Y=\beta_{0}+\beta_{1} x_{1}+\beta_{2} x_{2}+\beta_{3} x_{3}+\beta_{4} x_{4}+\beta_{5} x_{5}+\beta_{6} x_{6}+\beta_{7} x_{7}+\beta_{8} x_{8}+\beta_{9} x_{9}+\beta_{10} x_{10}+\mathcal{E}$

Where:

$\beta_{0}=$ Constant

$x_{1}=$ Physical Control

$x_{2}=$ Authorization Control

$x_{3}=$ Personnel Control

$x_{4}=$ Arithmetic and Accounting

$x_{5}=$ Management Control

$x_{6}=$ Organizational Control

$x_{7}=$ Supervision Control

$x_{8}=$ Segregation of Duties

$x_{9}=$ Acknowledgement of Performance 
$x_{10}=$ Budget/ budgetary Control

$\varepsilon=$ The error term

\section{RESULTS AND DISCUSSION}

A total of 348 respondents returned their completed questionaire from the seven cooperative societies in the four tertiary institutions selected for the study, representing a response rate of $93.5 \%$. Out of these respondents $50.3 \%$ were male while $49.7 \%$ were female. Majority (72.6\%) falls between 31 and 50 years of age. These results indicate that both men and women considered membership of cooperative as very important and they are within the active working age. Almost all the respondents (96.6\%) had tertiary education.

\section{Types of Internal Control Measures Used by the Cooperative Societies in the Selected Tertiary Institutions}

Table 1 reveals the types of internal control measures used by the cooperative societies in the selected tertiary institutions in the study area. It was shown that the cooperative societies often use physical control measures (such as control over assets and records) $(\bar{X}=4.3)$, authorization $(\bar{X}=4.1)$, personnel control $(\bar{X}=4.0)$, as well as arithmetic and accounting control $(\bar{X}=4.1)$. It was further revealed that the cooperative societies in the tertiary institutions of the study area often use management control $(\bar{X}=4.3)$, organizational control $(\bar{X}$ $=4.1)$, supervision control $(\bar{X}=4.1)$, segregation of duties control $(\bar{X}=3.7)$, acknowledgement of performance $(\bar{X}=3.9)$, as well as budget / budgetary control $(\bar{X}=3.9)$. The fact that the selected cooperative societies often adhere to the principles of key internal control might be responsible for the relatively better performance of cooperative societies in tertiary institutions compared to some other cooperative societies that are not domiciled in tertiary institutions. This is in accordance with the findings of Idowu and Adedokun (2013), who reported that cooperative societies domiciled in tertiary institutions in Nigeria perform better due to their proper adherence to the principles of internal control measures as compared to other cooperatives that are not institutionally based. 
European Journal of Accounting, Auditing and Finance Research

Vol.8, No.2, pp.81-99, February 2020

Published by ECRTD-UK

Print ISSN: 2053-4086(Print), Online ISSN: 2053-4094(Online)

Table 1: Types of Internal Control Measures Used by the Cooperative Societies in the Selected Tertiary Institutions

\begin{tabular}{|c|c|c|c|c|c|c|c|c|c|}
\hline $\begin{array}{l}\text { Types of internal control } \\
\text { measures used by the cooperative } \\
\text { societies }\end{array}$ & $\begin{array}{l}\text { Very } \\
\text { often } \\
5\end{array}$ & $\begin{array}{l}\text { Often } \\
4\end{array}$ & $\begin{array}{l}\text { Optio } \\
\text { Less } \\
\text { often } \\
3\end{array}$ & $\begin{array}{l}\text { Seldom } \\
2\end{array}$ & $\begin{array}{l}\text { Rarely } \\
1\end{array}$ & $\mathbf{F}$ & $\Sigma \mathbf{f} \mathbf{x}$ & $\overline{\mathbf{X}}$ & Decision \\
\hline Physical control & 164 & 143 & 14 & 9 & 12 & 342 & 1464 & 4.3 & Often \\
\hline Authorization & 131 & 157 & 34 & 12 & 9 & 343 & 1418 & 4.1 & Often \\
\hline Personal control & 118 & 139 & 49 & 19 & 15 & 340 & 1346 & 4.0 & Often \\
\hline Arithmetic and accounting & 151 & 111 & 34 & 30 & 10 & 336 & 1371 & 4.1 & Often \\
\hline Management control & 138 & 117 & 41 & 14 & 29 & 339 & 1338 & 3.9 & Often \\
\hline Organizational control & 129 & 152 & 27 & 26 & 6 & 340 & 1392 & 4.1 & Often \\
\hline Supervision control & 123 & 151 & 45 & 15 & 7 & 341 & 1391 & 4.1 & Often \\
\hline Segregation of duties & 92 & 133 & 65 & 29 & 20 & 339 & 1265 & 3.7 & Often \\
\hline Acknowledgement of performance & 109 & 146 & 43 & 23 & 16 & 337 & 1320 & 3.9 & Often \\
\hline Budget / budgetary control & 125 & 137 & 33 & 20 & 24 & 339 & 1336 & 3.9 & Often \\
\hline
\end{tabular}

Note: Very often $=\geq 4.5 ;$ Often $=3.5-4.49 ;$ Less often $=2.5-3.49 ;$ Seldom $=1.5-2.49 ;$ Rarely $=<1.5$ 
Vol.8, No.2, pp.81-99, February 2020

Published by ECRTD-UK

Print ISSN: 2053-4086(Print), Online ISSN: 2053-4094(Online)

Factors Affecting the Adoption of Internal Control Measures Used by the Cooperative Societies in the Study Area

Table 2 presents the factors affecting the adoption of internal control measures used by the cooperative societies in the study area. Respondents agreed that the mode of payment $(\bar{X}=$ $3.5)$ is a factor that affects the adoption internal control measures of the selected cooperative societies in tertiary institutions in the study area. However, the respondents are unable to decide if over granting loan to members $(\bar{X}=2.7)$, poor segregation of duties $(\bar{X}=2.8)$, inadequate collateral security $(\bar{X}=3.0)$ and lack of supervision $(\bar{X}=2.9)$ are factors that affect the adoption internal control measures of the cooperative societies of selected tertiary institutions in the study area. It was further revealed that the respondents were unable to decide if inadequate protection of organization assets $(\bar{X}=2.9)$, lack of inflow of cash in cooperative society $(\bar{X}=3.2)$, poor notification of management personnel during the movement of equipment and resources from one location to another $(\bar{X}=2.7)$, undue dominance from the executives $(\bar{X}=2.8)$ and inappropriate approval of loans $(\bar{X}=2.8)$. 
European Journal of Accounting, Auditing and Finance Research

Vol.8, No.2, pp.81-99, February 2020

Published by ECRTD-UK

Print ISSN: 2053-4086(Print), Online ISSN: 2053-4094(Online)

Table 2: Factors Affecting the Adoption of Internal Control Measures Used by the Cooperative Societies in the Study Area

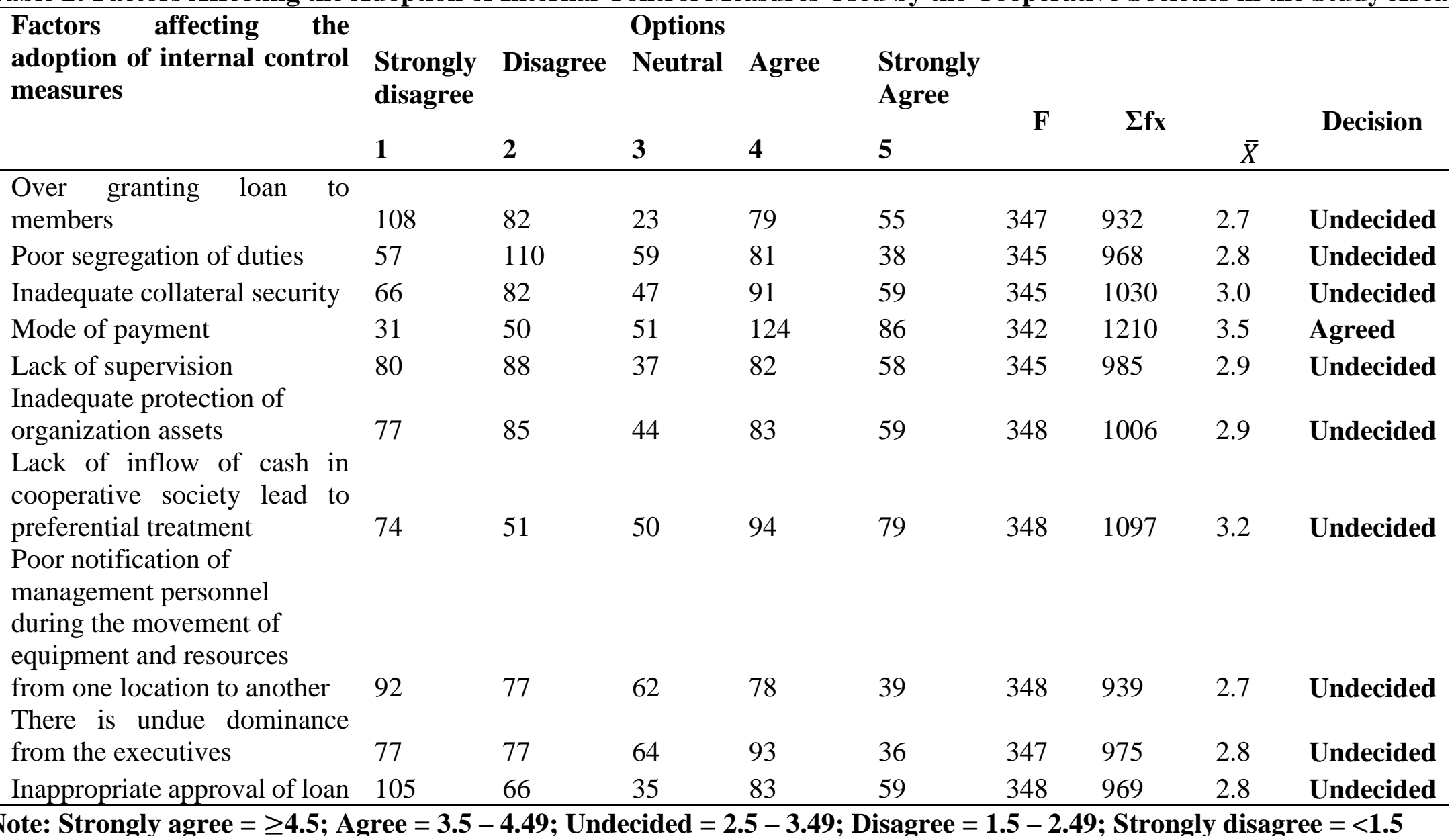


Approval of loan $(\bar{X}=2.8)$ are factors that affects the adoption internal control measures of the cooperative societies of selected tertiary institutions in the study area. The fact that the mode of repayment $(\bar{X}=3.5)$ is the only significant factor that affect the adoption of internal control can be attributed to the fact that mode of loan repayment is a key factor that determines the effectiveness of any other internal control measure used by the cooperative society.

\section{Effectiveness of Internal Control System on Cooperative Societies Performance in the Study Area}

The effectiveness of internal control system on cooperative society's performance in the study area were presented in Table 3. It was revealed that the types of internal control that significantly affect the performance of cooperative societies in the study area include authorization measure $(\mathrm{p}=0.027)$, arithmetic and accounting measures $(\mathrm{p}=0.000)$, as well as budgetary measures $(\mathrm{p}=0.001)$. It was also revealed that a positive relationship exists between the dependent variable (performance of cooperative societies) and the significant independent variables. This implied that the more authorization measures, arithmetic and accounting measures, as well as budgetary measures applied to the operations of cooperative societies, the more effective is the performance of the cooperative societies in the study area. It was further revealed that the coefficient of multiple determinations (R-square) is 0.716 . This implied that $71.6 \%$ of the variation/changes in the effectiveness of internal control system of cooperative societies is accounted for by the variables included in the model and the constant term, while the remaining is accounted for by the error term. 
Print ISSN: 2053-4086(Print), Online ISSN: 2053-4094(Online)

Table 3: Effectiveness of Internal Control System of on the performance of

Cooperative Societies in the Study Area

\begin{tabular}{|c|c|c|c|c|c|}
\hline Factors & Coefficients & Std. Error & Beta & t-value & p-value \\
\hline (Constant) & 1.993 & 0.290 & & 6.882 & 0.000 \\
\hline Physical Control & 0.037 & 0.044 & 0.046 & 0.834 & 0.405 \\
\hline Authorization & $0.108 * *$ & 0.049 & 0.135 & 2.222 & 0.027 \\
\hline Personnel control & -0.041 & 0.041 & -0.059 & -1.006 & 0.315 \\
\hline $\begin{array}{l}\text { Arithmetic and } \\
\text { accounting }\end{array}$ & $0.152 * *$ & 0.043 & 0.224 & 3.534 & 0.000 \\
\hline Management control & 0.045 & 0.038 & 0.075 & 1.201 & 0.231 \\
\hline Organizational control & 0.010 & 0.046 & 0.012 & 0.209 & 0.834 \\
\hline Supervision control & 0.044 & 0.048 & 0.054 & 0.902 & 0.368 \\
\hline Segregation of duties & -0.044 & 0.039 & -0.069 & -1.151 & 0.251 \\
\hline $\begin{array}{l}\text { Acknowledgement of } \\
\text { performance }\end{array}$ & -0.001 & 0.042 & -0.002 & -0.034 & 0.973 \\
\hline $\begin{array}{l}\text { Budget / budgetary } \\
\text { control }\end{array}$ & $0.137 * *$ & 0.040 & 0.210 & 3.402 & 0.001 \\
\hline \multicolumn{6}{|c|}{$\begin{array}{l}\text { a. Dependent Variable: Performance of cooperative society } \\
\text { R-Square }=\mathbf{0 . 7 1 6} \\
* *=\text { Significant at } 5 \%\end{array}$} \\
\hline
\end{tabular}

Source: Data Analysis, 2019.

\section{Effectiveness of Internal Control System on the Performance of the Cooperative Societies in the Study Area}

Table 4 presents the effectiveness of internal control system on the performance of the cooperative societies in the study area. The respondents agreed that appropriate approval of loan before payment $(\bar{X}=3.9)$, review of meeting of previous loan disbursement $(\bar{X}=$ 3.9), physical security of assets $(\bar{X}=3.7)$ and deduction of bad debt $(\bar{X}=3.6)$ are effective internal control measure that affect the performance of cooperative societies in the study area.It was also revealed in table 4 that the respondents agreed that availability of relevant information regarding legislation and regulatory development that may affect the cooperative $(\bar{X}=3.8)$, key information about 
the cooperative operations identified and regularly reported $(\bar{X}=3.8)$, adequacy of handling conflicts of interest in the cooperative $(\bar{X}=$ $3.7)$, investigation and prompt handling of complaints internally and externally $(\bar{X}=3.9)$, possibility of quick loan disbursement $(\bar{X}=$ $3.9)$, as well as dividends and incentives given to qualified cooperative members $(\bar{X}=4.2)$, are effective internal control measures that affect the performance of cooperative societies in the study area.

\begin{tabular}{|c|c|c|c|c|c|c|c|c|c|}
\hline \multirow{2}{*}{$\begin{array}{l}\text { Effectiveness of internal control system on } \\
\text { the performance of the cooperative societies }\end{array}$} & \multirow[b]{2}{*}{$\begin{array}{c}\text { Strongly } \\
\text { disagree } \\
1\end{array}$} & \multirow[b]{2}{*}{$\begin{array}{c}\text { Disagree } \\
2\end{array}$} & \multicolumn{2}{|l|}{ Options } & \multirow[b]{2}{*}{$\begin{array}{c}\text { Strongly } \\
\text { Agree } \\
5\end{array}$} & \multirow[b]{2}{*}{$\mathbf{F}$} & \multirow[b]{2}{*}{$\Sigma \mathbf{f} \mathbf{x}$} & \multirow[b]{2}{*}{$\overline{\boldsymbol{X}}$} & \multirow[b]{2}{*}{ Decision } \\
\hline & & & $\begin{array}{c}\text { Neutral } \\
\mathbf{3}\end{array}$ & $\begin{array}{c}\text { Agree } \\
4\end{array}$ & & & & & \\
\hline Appropriate approval of loan before payment & 45 & 16 & 13 & 140 & 132 & 346 & 1336 & 3.9 & Agree \\
\hline Review meeting of previous loan disbursement & 11 & 40 & 29 & 154 & 112 & 346 & 1354 & 3.9 & Agree \\
\hline Physical security of assets & 19 & 26 & 57 & 167 & 76 & 345 & 1290 & 3.7 & Agree \\
\hline $\begin{array}{l}\text { Deduction of bad debt } \\
\text { Availability of relevant information regarding } \\
\text { legislation and regulatory development that } \\
\text { may affect the cooperative }\end{array}$ & 17 & 47 & 62 & 147 & 68 & 341 & 1225 & 3.6 & Agree \\
\hline $\begin{array}{l}\text { Key information about the cooperative } \\
\text { operations identified and regularly reported }\end{array}$ & 31 & 15 & 40 & 172 & 88 & 346 & 1309 & 3.8 & Agree \\
\hline $\begin{array}{l}\text { Adequacy of handling conflicts of interest in } \\
\text { the cooperative }\end{array}$ & 14 & 44 & 50 & 168 & 67 & 343 & 1259 & 3.7 & Agree \\
\hline $\begin{array}{l}\text { Investigation and prompt handling of } \\
\text { complaints internally and externally }\end{array}$ & 14 & 28 & 41 & 167 & 96 & 346 & 1341 & 3.9 & Agree \\
\hline Possibility of quick loan disbursement & 18 & 31 & 32 & 165 & 99 & 345 & 1331 & 3.9 & Agree \\
\hline $\begin{array}{l}\text { Dividends and incentives are given to qualitied } \\
\text { cooperative members }\end{array}$ & 16 & 15 & 26 & 125 & 163 & 345 & 1439 & 4.2 & Agree \\
\hline
\end{tabular}

Note: Strongly agree $=\geq 4.5 ;$ Agree $=3.5-4.49 ;$ Undecided $=2.5-3.49 ;$ Disagree $=1.5-2.49 ;$ Strongly disagree $=<1.5$ 
European Journal of Accounting, Auditing and Finance Research

Vol.8, No.2, pp.81-99, February 2020

Published by ECRTD-UK

Print ISSN: 2053-4086(Print), Online ISSN: 2053-4094(Online)

\section{Implication to Research and Practice}

This study contributed to the existing body of knowledge by establishing how well the tertiary institutions based cooperative societies performance are influenced by the use of internal control system. The study established the key factors that significantly affect the effectiveness of internal control system of cooperative societies in tertiary institutions in the study area..

\section{CONCLUSION AND RECOMMENDATIONS}

The study revealed that the cooperative societies often use all the key internal control measures, the mode of payment is a factor that affects the adoption of internal control measures of the selected cooperative societies in tertiary institutions in the study area, while the factors that significantly affect the effectiveness of internal control system of cooperative societies in the study area include authorization measure $(\mathrm{p}=0.027)$, arithmetic and accounting measures $(\mathrm{p}=0.000)$, as well as budgetary measures $(\mathrm{p}=0.001)$. Timely approval of loan for members, review meeting of previous loan disbursement and physical security of assets are effective internal control measures that affect the performance of cooperative societies in the study area. It was however concluded that there is significant influence of internal control on the performance of cooperative societies in the study areas.

Based on the findings of this study, the following recommendations are made to improve the performance of internal control systems in the cooperative societies in some selected tertiary institutions in Ondo States, Nigeria.

(i) There should be a proper implementation of guiding principles of cooperative societies in tertiary institutions with respect to mode of loan repayment, and other qualifying measures for cooperative membership. This is expected to guarantee proper accountability and also guide against possible default situations that may arise from some members.

(ii) Emphasis should be placed on the control of presenting pay slip evidence before loan application is considered to ensure that members do not take loans that cannot be effectively repaid within the stipulated period.

(iii) The Cooperative societies in the tertiary institutions should have specific guidelines on the implementation of necessary internal controls on granting and repayment of loans.

\section{Future Research}

In view of the significant contribution of cooperative societies to micro financing in Nigeria, the scope of this research could be extended to include tertiary institutions in all the six geopolitical zones in Nigeria as well as other cooperative societies in other sectors of the economy. 
European Journal of Accounting, Auditing and Finance Research

Vol.8, No.2, pp.81-99, February 2020

Published by ECRTD-UK

Print ISSN: 2053-4086(Print), Online ISSN: 2053-4094(Online)

\section{REFERENCES}

Agwu, G. (2006): Problems of Microfinance in Nigeria. Ita Press, Enugu. Pp 17-29

Arigbadu, Y.D.(2012): The Impact of Co-operative Society on Capital Formation (A Case Study of Temidire Co- operative and Thrift Society, Ijebu-Ode, Ogun State, Nigeria), Global Journal of Science Frontier Research Agriculture and Veterinary Sciences, 12(11):17-29.

Asiligwa, G. and Rennox R. (2017): The effect of internal control on the financial performance of commercial bank in Kenya. Journal of economics and finance vol 8,pp 92-105.

Ayagre, P., Appiah-Gyamerah, I. and Nartey, J. (2014): The effectiveness of internal control systems of banks: The case of Ghanaian banks. International Journal of Accounting and Financial Reporting, 4(2), 377-389.

Badmus, M.A. (2012): The Impact of Co-operative Society on Capital Formation (A Case Study of Temidire Co- operative and Thrift Society, Ijebu-Ode, Ogun State, Nigeria), Global Journal of Science Frontier Research Agriculture and Veterinary Sciences, 12(11):17-29.

Barney, J. B. (1991). "Firm resources and sustained competitive advantage." Journal of Management, 17, pp. 99-120.

Bayyoud, M. and Syyad, A. (2015): The Impact of Internal Control and Risk Management on Banking Palestine, International Journal of Economics, Finance and Managemet Science, 3(3), 156-161.

COSO (2013): Framework. Retrieved from https://www.pwc.com/us/en/forensic-Financial Reporting Council (2014), 'Guidance on risk management, internal control and related financial and business reporting. Retrieved from https://www.frc.org.uk/OurWork/Publications/Corporate-Governance/Guidance-on-Risk-Management,-InternalControl-and.pdf

Ejoh, N. and Ejom, P. (2014): The Impact of Internal Control Activities on Financial Performance of Tertiary Institutions in Nigeria.Journal of Economics and Sustainable Development, 5 (16), 133-143.

Frazer, L. (2011): The Effect of Internal Control on the Operating Activities of Small Restaurants. Journal of Business and Economics Research, 16(6), 361-374.

Gertler, M. (2001): Rural Co-operatives and Sustainable Development, Saskatoon SK: Centre for the Study of Cooperatives, University of Saskatchewan pp 4-13

Gibson, R. (2005): The Role of Cooperatives in Community Economic Development, RDI Working Paper No 2005-3.

Idowu, A. and Adedokun, O. (2013): Internal Control System on Fraud Detection: Nigeria Experience. Journal of Accounting and Finance. Vol. 13(5), pp.141-152.

Hayali, A., Dinc, Y., Sarih, S., and Dizman, A. S. (2012): Importance of Internal Control Systems in the Banking Sector: Evidence from Turkey. Thesis. [42].

Kareem,R.O., Arigbabu, Y.D., Akintaro, J.A. and Badmus, M.A. (2012): The Impact of Cooperative Society on Capital Formation(A Case Study of Temidire Co- operative and Thrift Society, Ijebu-Ode, Ogun State, Nigeria), Global Journal of Science Frontier Research Agriculture and Veterinary Sciences, 12(11): pp17-29. 
Magara, N. (2013): Effect of Internal Control on Deposit Taking Savings and Credit Cooperative Societies.Research Project for The Award Of M.Sc., University of Nairobi.

Mary, M., Albert, O. and Byaruhanga, J. (2014): Effects of Internal Control Systems on Financial Performance of Sugarcane Out Grower Companies in Kenya. IOSR Journal.pp 62-73

Mendoza, R.R. (2012): Accountancy Research Theory and Practice, Manila Phillipines, Domdane Publishers pp. 23-37

Otto, G. and Ukpere, W. (2011):Credit and thrift co-operatives in Nigeria: A potential source of capital formation and employment. Emhai Pub. Port Harcourt. pp 27-43

Ratcliffe, M. (2009): The Basics of Internal Control. Institute of Internal AuditorTopeka Chapter, Retrieved from http://www.theiia.org/chapters/pudducs/242/International Control Basics 11A 040709.pdfRobbins, S. (1992):

Simon, H. A. (1945). Administrative Behavior. New York: Free Press.pp 19-43

Taylor, R.A. (1974): Credit Unions and Cooperative Banking in Developed and Developing Countries, Annals of Public and Cooperative Economy, Germany. https://doi.org/10.1111/j.1467-8292.1974.tb00784.X

Wardiwiyono, S. (2012): Internal control system for lslamic micro financing. lnternational Journal of lslamic and middle eastern finance and management, 340-352.

Whittingon, O.R. and Pany, K. (2001): Principles of Auditing and other Assurance Services. Irwin/ McGaw-Hill. New Yorks p. 67-91 